\title{
SPACE INVADERS-TIME RAIDERS: Gendered Technologies in Gendered UK Households
}

\author{
Helen J. Richardson \\ University of Salford \\ Salford, U.K.
}

\begin{abstract}
This paper discusses the domestication of ICTs in the UK, using a critical lens to focus in on ICT use by families and households drawing on a 5 year longitudinal study. Analysis concentrates on how ICTs are embedded into gendered households, how issues of gendered technologies are manifested in the everyday experiences of women, enmeshing ICT use for work, study, and leisure into domestic family life. The social, political, economic, and historical context is that of versions of inchusion in the so-called information society - a debate that wavers between a somber and shining vision.
\end{abstract}

Keywords Domestication of ICTs, gendered technology, gendered family, versions of inclusion

\section{INTRODUCTION}

Using a critical lens, this paper focuses in on ICT use by families and households in the UK. The household is a complex social, economic, and political space that powerfully affects both the way technologies are used and their significance (Silverstone and Hirsch 1992). We know little about the economic or social context of the use of technologies in the home or how ICTs are appropriated and consumed in households, ${ }^{1}$ including the gender dimensions of this and the negotiation involved (Green 2001). A feature of the UK family today is the blurring of the private and public as working at home increases and the importance of the home takes on new significance with what is

'Although studies are emerging, for example from the EMTEL network (European Media and Technology in Everyday Life, www.emtel2.org).

Please use the following format when citing this chapter:

Richardson, H.J., 2006, in IFIP International Federation for Information Processing, Volume 208, Social Inclusion: Societal and Organizational Implications for Information Systems, eds. Trauth, E., Howcroft, D., Butler, T., Fitzgerald, B., DeGross, J., (Boston: Springer), pp. 169-184. 
private and what is public becoming hazy (Huws 2003). In this context, how are ICTs domesticated? Who is using what, why, when, and how in the home? My argument is that even the mundane and everyday reveals complex ideas and struggles and to make sense of home ICT use in gendered households needs a critical analysis that cuts through the myriad of often contradictory notions that shape people's lives, "connecting the ideas with the material world in which people live and think" (Harman 2005, p. 21).

Placing the domestication of ICTs in the UK specifically in its social, political, economic, and historical context has wide relevance in many arenas. There are contending discourses of government, education, ICT manufacturing, and parents in innovation research (Haddon 1992). There are versions of what inclusion in the socalled information society means. Brants and Frissen (2003) find that the debate wavers between a somber and shining vision, with the optimists positioning the Internet as an enabling technology, for example leading to empowerment and greater social justice. The pessimists talk about ICTs as intrusive and the domain of inclusion and exclusionthe digital divide-being a development strengthened by existing divides and inequalities with the marginalized being excluded from the information society. As Brants and Frissen point out, both visions seem to be inspired by technological determinism. In this paper, I argue that inclusion strategies cannot happen in a vacuum (Kvasny and Keil 2006) and analyses are limited if the dynamics of family life, and gender and technology relations, are overlooked.

This research fundamentally aims to advance critical research in Information Systems and, to this end, broaden understanding of ICT use in everyday life. To take critical research in IS forward, Howcroft and Trauth (2004) suggest that research should describe the relevant underlying structures of social and material conditions and explain how they shape and determine the nature and content of IS and the ways they mediate work. It should assist in demystifying the myths of technological determinism, enable exposure of taken-for-granted assumptions, provide an insight into the broader social, organizational, and political implications of IS. It should enable both researchers and the researched to see or envision the desired changes. To this end, I draw on a longitudinal study of primarily women in seven UK households from 1999 to 2004 and six self-selected in-depth interviews of women known to me to use ICTs in the home and conducted during 2004. I analyze how ICTs are embedded into gendered households, how issues of gendered technologies are manifested, and the everyday experiences of women enmeshing ICT use for work, study, and leisure into everyday domestic family life. In conclusion and comment, I call for an alternative version and vision of the future free from commercial and governmental discourse centering as it does on digital inclusion for the contributions citizens can thus make to economic and social stability. I also call for more research into the neglected area of ICTs and families, households, and everyday lives often rooted as it currently is, in flawed views of technological determinism and gender neutrality.

This paper will proceed by discussing the family and households in the UK and the domestication of technologies, in particular ICTs. From the context of versions of inclusion, I give an overview of examples of research that consider ICT use in domestic settings using the typology of the household, gender, and technology as a critical discursive tool. I then present my research methodology and provide illustrative commentary from my qualitative inquiry. 


\section{UK HOUSEHOLDS}

Considering ICT use in the home, the household becomes the focus of enhanced consumption and so the lens shifts to the family. Many policy makers and commentators decry the "new family" in the "new economy." German (2003) points out that, in the UK, there has been a dramatic increase in single-parent households in the past two decades. However, as she explains, while the family is broken down by the effects of capitalism, it is also maintained and reinforced by capital as the cheapest, most convenient, and most socially stable way of caring for the existing generation of workers and reproducing the next generation. The family is also a gendered institution and is often taken for granted. Wharton (2005) describes how the family is viewed as "somehow functional for society rather than a social construction and changing in relation to history and culture" and she continues to observe that, although family diversity is a social fact, this is "obscured by a set of taken-for-granted beliefs about the family as a social institution" (p. 105). These include myths of the nuclear family, the heterosexual family, women as mothers and caretakers, and men as fathers and breadwinners. However, it is these myths that inform the choices made, including government and employment policies. So in summary, UK domestic households cannot be considered apart from consideration of gender and the role of the family in capitalism today and this includes gendered ways of knowing and being which become an "inextricable part of the intimate details of everyday life" (Silva 2000).

Wajcman (1991) discusses how housework began to be presented as an expression of the housewife's affection for her family. The split between public and private meant that the home was expected to provide a haven from the alienated, stressful technological order of the workplace and was expected to provide entertainment, emotional support, and sexual gratification. The burden of satisfying these needs fell on the housewife (pp. 85-86). The gender politics of the household and sexual division of domestic labor are reflected in surveys of gender and housework today. Kan (2001, p. 6), for example, uses the British panel household survey and analyzes that, in general, women in the UK spend 18.5 hours a week doing housework and men just over 6 .

In terms of the domestication of technology, Wajcman (2000) discusses the early debates around domestic technologies, particularly the paradox that despite mechanization of the house this hasn't substantially decreased the amount of time women spent on household tasks. Although in the domestic sphere many technologies are used by women - from the microwave to the washing machine, yet the "world of technology is made to feel remote and overwhelmingly powerful" (Faulkner 2000, p. 80). The notion of "hard" technology-use of industrial machinery, or solitary geeks programming computers - is commonly associated with a masculine world of work, whether or not women are engaged in these occupations. Hard technology implies a dualism of "soft" technology-like domestic technology and ICTs used by women in clerical work, for example. In these terms, the hard-soft dualism factors out those other technologies which we all meet on a daily basis and can in some sense relate to (Faulkner 2000). In conclusion, many changes between the household and economy passed almost unrecorded (Huws 2003), yet without an understanding of these changes it is difficult to grasp the impact of ICTs on the home and everyday life. 


\section{THE DOMESTICATION OF ICTS IN THE CONTEXT OF INCLUSION}

How does the domestication of ICTs fit in here, then? How are ICTs appropriated and consumed in UK households? Green and Adam (1998) have observed the gendered social relation of domesticity that surrounds the use of ICTs. Research such as the Home Net project has shown how home computers are used predominantly for communication by adults in households (Boneva et al. 2001), although PCs are often bought with children's education in mind. In this context, women often view the home computer as a shared family resource. Research indicates that men are much more likely to see the computer as belonging to them and therefore prioritize their access (Richardson and French 2002). Home PC ownership has a strong association with the daily bombardment of digital divide rhetoric as well, demanding an individual commitment and responsibility to self-help. In other words, the message is, embrace the ICT revolution or be a victim of digital "have-not-ness" brought about, it is implied, by personal inadequacy and culpable neglect. Many people in this study are "catching hell" (Kvasny 2004) living busy lives with an overload of domestic and work commitments in the everyday struggle to make ends meet. Use of ICTs in the home in this context is just another thing to be dealt with.

What the discourse about the transformational impact of ICTs (Mandleson 2001) reveals is a burning wish to direct the future, regarded by Wajcman (2000) as symbolic and a highly valued and mythologized activity. Yet there are versions of the future. Moore (2003) describes the corporate versions that seek to produce corporate identities presenting a future that is ultimately knowable through expertise resting on the valued endpoint of competitive advantage. She continues to highlight the inexorable logic of future-orientated technological determinism. Of course the urge to consume ICTs in a domestic setting is inevitably linked to domestication of new media and communication devices and is very attractive to this corporate vision. Ward (2003) notes how discourse surrounding inclusion centers around consumers engaging with the information society with e-commerce being seen as synonymous to this, implying that users need to learn how to consume, not only to participate within but also to construct the information society. In the context of everyday life, it is important to dissect the limits and misunderstandings embedded in the rhetoric of the information society to challenge the presumptions of rationality and efficiency operationalized as they so often are in a discourse of consumer need (Ward 2003). Brants and Frissen (2003, p. 6) observe that there is a strong emphasis in digital divide discourse on quantitative data such as PC ownership and this is correlated to socio-demographic characteristics of potential users, for example the level of education and skill. They continue that while perhaps this is helpful to identify "laggers," marginalized groups are thus often stigmatized and such a perspective tells us little about the skills, capacities, or other highly relevant dimensions of the everyday lives of these stragglers. The specific contexts, dynamics and dimensions of inclusion or exclusion thus remain under researched. The future and what technologies we have and how they are used are not inevitable. Domestication of ICTs in this context highlights a dominant viewpoint of the essentialist assumptions held about technologies and those that consume them. 


\section{ICTS IN THE HOME: A CRITICAL LITERATURE REVIEW}

Steward and Williams (2005, p. 203) concluded that domestication--or appropriation - of technologies (in research) tends to be about where the product is located or how it is incorporated within family routines, but they suggest that a broader view is that domestication is about taming the technology-how ICTs are used in unanticipated ways and the integration of ICTs within their particular contexts and purposes.

There are a small but growing number of studies that consider ICTs in the home These sometimes originate from commercial considerations, for example the research from "BT exact" published in various volumes of British Telecom's BT Technology Journal (for example, see volume 17, 1999, and volume 20,2002). Other studies are concerned with user-centered design and HCI considerations (e.g., Baille et al. 2003; Phillips et al. 2001). These studies focus on "smart homes" characterized as being "intelligent, connected and wireless" (Patel and Pearson 2002, p. 106). Use of technology in the home involves issues such as the extent to which the Internet had an impact on the way interviewees spent their time and how Internet use displaced other activities and as such what can be done to maximize money-making potential (Anderson et al. 2002, p. 15). The driving force of much research is to highlight the benefits of a digital home described as offering flexibility (services available when and where wanted), peace of mind (safety when away, independence for older people, and so on), and saving money, for example, "time-shifting activities to benefit from cheapest energy supply, monitoring energy use, reducing waste and controlling your home climate" (Rout 2002, p. 103). Other studies discussing technology in the home are more sociologically driven, some taking a feminist approach that, in my view, provides a richer view of the domestication of technologies within dynamic and gendered households. Hynes (2002) also notes that study of consumption of ICTs is often a number-crunching exercise and that quantitative discourse pervades - in other words, trying to profile a typical user buying a particular brand in a technology-driven strategy. Often studies tend to adopt a determinist position with regard to gender, so they also adopt a determinist position with regard to the technology, tending to see it as fixed and inevitable in its introduction and use (Adam et al. 2004). So both gender and technology need to be problematized, to be seen as cultural products rather than as "givens."

When reviewing this literature, it astounded me how little the household itself was analyzed in some of the studies and how gender and technology were not problematized or even considered worthy of any comment. Rather than a "haven or hell" described above, I came away from reading some studies with a view of households as sterile places, neutral and bland. I propose that research wishing to consider how ICTs are appropriated, used, or "tamed" in the domestication process should provide analysis of the household context, the gendered family, and theorize technology. Using this typology, I have summarized some examples of studies that discuss technology in the home in Table 1.

Following this debated version of inclusion, I now introduce my research methodology and analysis, applying the typology utilized above. 
Table 1. Summary of Some Examples of Literature Discussing Technology in the Home

\begin{tabular}{|c|c|c|c|c|}
\hline Authors & Study & $\begin{array}{l}\text { View of the } \\
\text { Household }\end{array}$ & Gender Analysis & $\begin{array}{c}\text { View of } \\
\text { Technology }\end{array}$ \\
\hline $\begin{array}{l}\text { Anderson et } \\
\text { al. (1999) }\end{array}$ & $\begin{array}{l}\text { Family life in the } \\
\text { digital home: } \\
\text { how and why } \\
\text { people purchase } \\
\text { and adapt to ICTs }\end{array}$ & $\begin{array}{l}\text { Consists of } \\
\text { individuals within } \\
\text { a family structure }\end{array}$ & A variable & $\begin{array}{l}\text { Not considered or } \\
\text { theorized }\end{array}$ \\
\hline $\begin{array}{l}\text { Anderson et } \\
\text { al. (2002) }\end{array}$ & $\begin{array}{l}\text { People-centered } \\
\text { innovation and } \\
\text { strategy }\end{array}$ & $\begin{array}{l}\text { Unproblematic } \\
\text { and non-theorized }\end{array}$ & Not considered & $\begin{array}{l}\text { Understanding } \\
\text { usage by people } \\
\text { important for } \\
\text { money making } \\
\end{array}$ \\
\hline $\begin{array}{l}\text { Baille et al. } \\
(2003)\end{array}$ & $\begin{array}{l}\text { The design of } \\
\text { interactive } \\
\text { technologies and } \\
\text { household settings }\end{array}$ & $\begin{array}{l}\text { Home as living } \\
\text { space comprising } \\
\text { of social, technol- } \\
\text { ogical and physi- } \\
\text { cal space (from } \\
\text { Venkatesh 1996) } \\
\end{array}$ & Not analyzed & $\begin{array}{l}\text { User-centered } \\
\text { usability of } \\
\text { technological } \\
\text { artifacts informs } \\
\text { research }\end{array}$ \\
\hline $\begin{array}{l}\text { Cronberg and } \\
\text { Sangregorio } \\
\text { (1981) cited } \\
\text { in Huws } \\
(2003)\end{array}$ & $\begin{array}{l}\text { Impact of IT on } \\
\text { domestic life in } \\
\text { Japan }\end{array}$ & $\begin{array}{l}\text { Not theorized or } \\
\text { considered }\end{array}$ & $\begin{array}{l}\text { As a result of } \\
\text { methodology, sub- } \\
\text { jects were largely } \\
\text { women at home; } \\
\text { not theorized } \\
\end{array}$ & Advantageous \\
\hline $\begin{array}{l}\text { Green and } \\
\text { Adam (1998) }\end{array}$ & $\begin{array}{l}\text { ICTs and leisure } \\
\text { in the home }\end{array}$ & $\begin{array}{l}\text { Contested and } \\
\text { gendered social } \\
\text { space }\end{array}$ & $\begin{array}{l}\text { Feminist } \\
\text { approach; gender } \\
\text { necessitates } \\
\text { theorization } \\
\end{array}$ & $\begin{array}{l}\text { Socially shaped; } \\
\text { gender and } \\
\text { technology co- } \\
\text { constructed }\end{array}$ \\
\hline $\begin{array}{l}\text { Habib and } \\
\text { Cornford } \\
(2002)\end{array}$ & $\begin{array}{l}\text { Integration of the } \\
\text { home PC into } \\
\text { domestic spaces }\end{array}$ & $\begin{array}{l}\text { Multigenerational; } \\
\text { complex units of } \\
\text { values, relation- } \\
\text { ships, symbols, } \\
\text { and routines of } \\
\text { family life } \\
\end{array}$ & \begin{tabular}{|l|} 
Gender needs to \\
be theorized and \\
gender differences \\
and divides \\
identified
\end{tabular} & $\begin{array}{l}\text { Technology is } \\
\text { gendered }\end{array}$ \\
\hline $\begin{array}{l}\text { Morley } \\
(2000)\end{array}$ & $\begin{array}{l}\text { Home territories } \\
\text { and media, } \\
\text { mobility and } \\
\text { identity }\end{array}$ & $\begin{array}{l}\text { Symbolic } \\
\text { territory; locus of } \\
\text { power relations }\end{array}$ & $\begin{array}{l}\text { Space and homes } \\
\text { are gendered; } \\
\text { gender as a } \\
\text { geographical and } \\
\text { cultural construct }\end{array}$ & $\begin{array}{l}\text { Non-technological } \\
\text { deterministic } \\
\text { approach; tech- } \\
\text { nologies and their } \\
\text { use are contradic- } \\
\text { tory and involve } \\
\text { dynamic mutually } \\
\text { shaping relations } \\
\end{array}$ \\
\hline $\begin{array}{l}\text { Patel and } \\
\text { Pearson } \\
(2002)\end{array}$ & $\begin{array}{l}\text { Hype and reality } \\
\text { in the future home }\end{array}$ & $\begin{array}{l}\text { Unproblematic } \\
\text { and non-theorized }\end{array}$ & Not considered & Advantageous \\
\hline
\end{tabular}




\begin{tabular}{|c|c|c|c|c|}
\hline Authors & Study & $\begin{array}{l}\text { View of the } \\
\text { Household }\end{array}$ & Gender Analysis & $\begin{array}{c}\text { View of } \\
\text { Technology }\end{array}$ \\
\hline $\begin{array}{l}\text { Phillips et al. } \\
(2001)\end{array}$ & $\begin{array}{l}\text { The domestic } \\
\text { space as smart } \\
\text { environment }\end{array}$ & A design space & Not considered & $\begin{array}{l}\text { Domestic tech- } \\
\text { nologies support } \\
\text { personal, group, } \\
\text { or public devices } \\
\text { and dimensions of } \\
\text { control, binding to } \\
\text { people and inter- } \\
\text { faces; not } \\
\text { theorized }\end{array}$ \\
\hline Rout $(2002)$ & $\begin{array}{l}\text { Digital homes and } \\
\text { stakeholders }\end{array}$ & $\begin{array}{l}\text { Unproblematic } \\
\text { and non-theorized }\end{array}$ & Not considered & Advantageous \\
\hline Silva (2002) & $\begin{array}{l}\text { Time and emotion } \\
\text { in studies of } \\
\text { household } \\
\text { technologies }\end{array}$ & $\begin{array}{l}\text { Homes centrally } \\
\text { involve relation- } \\
\text { ships; households } \\
\text { can no longer } \\
\text { support an adult } \\
\text { as sole career in } \\
\text { the home } \\
\end{array}$ & $\begin{array}{l}\text { Dynamic gender } \\
\text { division of labor } \\
\text { and gender roles }\end{array}$ & $\begin{array}{l}\text { Technologies } \\
\text { impact on trans- } \\
\text { forming domestic } \\
\text { labor }\end{array}$ \\
\hline $\begin{array}{l}\text { Silverstone } \\
\text { and Hirsch } \\
\text { (ed) (1992) }\end{array}$ & $\begin{array}{l}\text { Consuming tech- } \\
\text { nologies; media } \\
\text { and information in } \\
\text { domestic spaces }\end{array}$ & $\begin{array}{l}\text { Social, cultural, } \\
\text { and economic unit } \\
\text { engaged in the } \\
\text { consumption of } \\
\text { objects and } \\
\text { meanings } \\
\end{array}$ & $\begin{array}{l}\text { Gender as largely } \\
\text { a cultural con- } \\
\text { struct }\end{array}$ & $\begin{array}{l}\text { Relational- } \\
\text { design, produc- } \\
\text { tion, use- } \\
\text { embodying gender } \\
\text { identity }\end{array}$ \\
\hline $\begin{array}{l}\text { Venkatesh } \\
\text { (1996) }\end{array}$ & $\begin{array}{l}\text { Capturing the } \\
\text { structure and } \\
\text { dynamics of com- } \\
\text { puter adoption in } \\
\text { the home }\end{array}$ & $\begin{array}{l}\text { Social organiza- } \\
\text { tion; main site of } \\
\text { technological } \\
\text { innovation and } \\
\text { development } \\
\end{array}$ & Not considered & $\begin{array}{l}\text { Usage involves } \\
\text { socially motivated } \\
\text { decisions }\end{array}$ \\
\hline Ward (2003) & $\begin{array}{l}\text { Ethnographic } \\
\text { study of Internet } \\
\text { consumption in } \\
\text { Ireland }\end{array}$ & $\begin{array}{l}\text { Domestic } \\
\text { culture-a } \\
\text { symbolic space }\end{array}$ & $\begin{array}{l}\text { Aspect of the } \\
\text { family and web of } \\
\text { human relations }\end{array}$ & $\begin{array}{l}\text { Intrusive, con- } \\
\text { strued with } \\
\text { meanings in defi- } \\
\text { nition, function, } \\
\text { use, and status } \\
\end{array}$ \\
\hline
\end{tabular}

\section{Research Methodology}

I began this enquiry in 1999 and at the outset I formed a focus group to guide the research and this shaped what is a longitudinal study of seven households and the domestication of ICTs within these households over the 5 year research period. In terms of my research, however, I used focus groups not only as an interviewing technique to gather information about each household and their experiences of the domestication of ICTs but also as a self-focus group to help me as a researcher to clarify and refine concepts, to observe, to place interaction at the center of the research process, and to explore attitudes, opinions, meanings, and definitions in the participant's own terms (Tonkiss 2004). 
The seven households representing the focus groups consisted of five households known to me and two that were new to my acquaintance at the start of the study but who were willing volunteers in the research. I attempted to include households with children and without, single households and shared, self-defined as heterosexual and gay although in the latter instance, there were two households involving lesbian relationships and no gay males were involved. This was important in thinking about the dynamics of households and family life, not taking the "family" for granted, as suggested by Wharton (2005) and discussed earlier. As you may expect, these households did not remain static but participants moved house and joined up with new partners and children grew, babies were born, and domestication of ICTs were shaped by the members in the households and shaped their everyday lives in turn.

The focus group households were involved with the research. We met up on a regular basis and the interviews were transcribed and reflexive stories written but always shown and discussed with the individuals and families concerned. It is important to think about myself as a critical researcher-as a woman with children, working full-time and studying as well, and using ICTs extensively in the home. Clearly the critical research approach in challenging the status quo, questioning assumptions and research practice informed by critical social theory impacted on the research process and the discussions held. Part of critical research is to let voices, often unheard, be heard, and so what follows are the personal stories of the family members in the focus group households and also those from the in-depth interviews. The six in-depth interviewees were women selected by me. They were known to me as women who used ICTs extensively in the home. However, prior to the interviews I had little idea about the extent of their ICT use, the field of study that was their households and family life or their attitudes to and experiences of technology.

All of the homes involved had a myriad of technological gadgets and ICTs. Most members of the households had a mobile phone; there were DVDs, TVs in many rooms, games consoles of every shape and hue, and one or more PCs housed mainly in shared household spaces. The qualitative enquiry in general centered on gaining an understanding of women's experiences with ICTs-in particular with PCs-in the home. In the following, analysis the participants came up with new names to ensure anonymity.

\section{ANALYSIS: THE HOUSEHOLD}

For the purposes of a critical study of ICT use, clearly an issue is how new technologies have impacted the household generally. The PC has particular significance in the home, often housed in communal space and taking up more physical space. In addition, the PC has a symbolic link embedding a subtext of personal improvement through its reported educative role. What the analysis draws out is that there is a process of domestication (Habib and Cornford 2002) of ICTs.

\subsection{ICTs as Space Invaders}

Where the PC is situated has an impact on family life. These interjections give an inkling of the dynamics involved. In the households visited, childcare is rarely far away 
for women in the home. Fran talked about an idealized time before the introduction of the laptop into the home.

We're scattered all around the house now instead of gathered together round the fire. He's [husband] doing his work somewhere. I' $m$ in the front room on this [laptop]. Then at the same time I'm trying to stop the kids playing football against the wall.

Laura and Jed's house was chaotic, with Laura trying to work in the kitchen and Simon, Matthew, and Mark in and out for food, a chat, to borrow money, and so on. Laura pointed to her kitchen table.

There's the PC on the kitchen table surrounded by mountains of paper-I don't know when we last had a family meal on the kitchen table. He [husband] gets annoyed, he says "I can't see the floor or the table. "Everything spills out onto the floor. Wires are hanging across the doorway and everyone has to step over them and the dog gets strangled. Then Mark shows me his Irish dancing in the middle of it!

Amanda showed me the $\mathrm{PC}$ in her dining room. It felt like a huge imposition on the communal space. She said,

It's here in the dining room-it clashes with everything-the TV, people talking. It's in the way but it's the only option.

\subsection{PCs for Work in the Home}

Some of the focus group households and in-depth interviewees spend a lot of time working at home and using the PC for that purpose and, for women in particular, this means juggling working time with family life as can be seen with the following observations. Laura was discussing working at home.

My kitchen is my office but the kids come in like a herd of elephants-in, out, in, out-because you're their mum, wherever you are and whatever you're doing.

Wilson and Greenhill (2004) suggest that home-working "magnifies the conflict of roles that women experience in attempting to equalize the work-life balance" (p. 43). One element of this is providing food at the time the family requires, clearly a role that women fulfill, and this can cause conflict with working at home. Laura discussed the impact on mealtimes.

I get so engrossed I forget everything else. I don't eat when I'm working but the kids are sometimes crying "where's my dinner." Family life goes on around me; sometimes I'm oblivious, like when the potatoes boiled dry and the pan went on fire! 
Erica also discussed how engrossing work becomes when using the PC.

One example, I put an egg on to boil for my son's tea. Son: "Is my egg ready?" Me: "Yeah in a minute." I'm clacking away on the PC, then 10 minutes have elapsed, another hard boiled egg. Son: "When am I ever going to get a runny egg again?" [Jamie then butted in: "I can do my own eggs now," and Erica responded] Yeah that's one good thing-they're so much more independent now.

\subsection{PCs for Study in the Home}

Some women face a great deal of domestic pressure when in education and are more likely to have to try to balance study, work, and home responsibilities, and student mothers often felt they had to reassure the family of the minimal repercussions their studies would have on family life in order to get approval (Maynard and Pearsall 1994). On-line courses can exacerbate domestic tensions for women, as Rachel suggests.

You feel guilty because you have to spread yourself between everything. I did spend some time explaining to the children that I was studying and then making it up to them in the holidays-still loads of guilt. After a while, they learn that when you are studying they leave you alone but I don't think husbands understand this.

Mary found using the PC for study was essential but very stressful, in particular fitting it into family life.

I find using the PC very stressful-I've got to go on the PC because of study but at home the cry is "are you on the computer AGAIN!"

The lives of some of the in-depth interviewees were changed beyond recognition through going to study. There was habitually a lot of support from the immediate family but often conflict from the wider family. Criticism centered on husbands, who were deemed to be neglected or let down. Not providing regular meals was often a bone of contention, as Erica described.

Before my access course we all sat down as a family for tea at 5:30 p.m. on the dot-access changed all that. It was a big thing to sit down together, now I couldn't give a [expletive]-it's not important to me anymore.

\section{ANALYSIS-GENDER PERSPECTIVES: ICTS AS TIME RAIDERS}

As stated earlier, all of the homes in the study housed a myriad of technological gadgets and ICTs. In analysis, it was evident that there was not only competition to use 
the technologies but also competition for the time that children and partners want and expect from the wife, mother, or female partner in the home, and this conflicted at times with women's use of ICTs. As Brants and Frissen (2003) observe, those who are marginalized in a socio-economic sense may still be well equipped with ICTs.

Women in the family are often leading busy lives and this can result in personal conflicts with a desire to spend time with the family and the pressures from using ICTs at home. The competing demands of labor market and domestic work are associated with a perception of a loss of control over time, often called "time crunch," and research suggests that women with children feel more time crunched than men (Peters and Raaijmakers 1999). Using ICTs in the home makes many feel time squeezed as a result of multiple role conflict and role overload (Peters and Raaijmakers 1999), with a feeling of loss of control over time. "Time just passes, " says Erica. "You never have time for anything," Laura notes. Work and home life boundaries blur and time needs to be negotiated.

Guilt is never far away, as can be seen from Erica's comment: "Sometimes I feel bad because I'm busy -I'm always busy on the computer." Amanda confirms this: "It gets too stressful and anyway I get sick of saying 'yeah in a minute.' I want to play, not be on the PC. I feel guilty when the kids want to use it."

In this analysis of the domestication of ICTs in UK households, women especially feel that they should be doing something else when using ICTs--guilt that spending time on things they want to do should happen after the household chores and family have been taken care of. Analysis indicated that negotiation is required in the relationships between adults in the household. One resource that is competed for is the time of women in the home and this causes stress if using ICTs takes women away from interaction with husbands and partners, as Laura suggests.

When he [husband] comes home from work, he doesn't do anything else and gets cheesed off if I' $m$ working all evening. He says, "Are you coming to bed?" Then he's very annoyed when I get in bed at 2 a.m. with freezing cold feet.

Working or studying at home and using ICTs often interfered with a husband's or partner's view of bedtime. This meant, in some cases, women trying to conceal the fact that they had been working on the PC. Amanda explained,

My PC was in the bedroom-very inconvenient. Sometimes [husband] had to sleep on the sofa if I was working, or I'd work in the dark but he'd complain. [Later she said,] I had to conceal when I went to bed-I'd creep in at 2 a.m. but if he woke up he'd say, "Are you stupid, what are you doing still working?

As Morley (2000, p. 56) has pointed out, "the home as a locus of power relations has often been almost entirely neglected."

Research in the UK suggests that families have the least amount of leisure time (MINTEL 2000). This report goes on to suggest that the pace of leisure has also become more frenetic as "it is squeezed between existing commitments of work and childcare." In this context, women increasingly have to juggle work, time, and money. They have 
less free time than ever before and the gap between their free time and that of men's is widening: "men retain their ability to do absolutely nothing for longer periods than women" (MINTEL 2000). Leisure is often viewed as a residual category by women but remains an unconditional entitlement for their male partners (Kay 1996). A striking feature of everyday life from my qualitative enquiry is how little leisure time people have or perceive themselves to have. Leisure time also is often taken in snatched and fragmented moments and at times that precludes preplanning. This concurs with Green's (2001) studies of women's leisure, revealing that time synchronization and time fragmentation dominates many women's lives in the UK, leading them to find snatched spaces for leisure and enjoyment rather than undertaking planned activities. In my qualitative enquiry, the question of time and unequal access to leisure featured heavily. In terms of domestic leisure Morley $(2000, p$. 72$)$ comments that women maintain primary responsibility for the smooth running of the home and for the reproduction of domestic order and comfort. This means, among other things, that domestic leisure remains heavily gendered.

\section{ANALYSIS: TECHNOLOGY}

In terms of understanding the use of technologies in everyday life, Silverstone (2003, p. 21) has noted how individuals, families, and groups make choices based on their own perceptions of their needs and values, and on the often-unconscious frameworks that guide their actions and interactions. In these terms, technologies do not emerge without active involvement of the consumers and users who have to accept them as relevant and useful in their everyday lives.

A theme raised by the qualitative enquiry relating to the domestication of ICTs is that of technological skill and how this relates to how gender and technology have been theorized. It is important to note the strong link between the notion of skill and masculinity, in particular technical skill, and how something becomes defined as a technical skill. Indeed Wajcman (1991) identifies technical skill and masculinity as mutually constitutive. As Grint and Gill (1995, p. 9) suggest, "Skill' is not some objectively identifiable quality, but rather is an ideological category, one over which women were (and continue to be) denied the rights of contestation."

There were some interesting tales to tell about the skills of ICT use and maintenance that support and contradict ideas of women and their lack or otherwise of technical ability. Gloria, for example, would constantly say how ignorant she was about computers: "I know nothing; I don't understand them." Despite this, through the 5 years of the study, she managed to install software, set up web cam facilities, work out how to scan and send pictures by e-mail, set up e-mail accounts, upgrade hardware, and troubleshoot printer problems. When this was pointed out, she would shrug: "Well I still don't understand them."

My qualitative enquiry uncovered no cliched pattern of male fascination and female avoidance of technology. Gender differences were in the free time available to use ICTs and views on priorities. Although many of the women were more experienced with technology, this didn't always go down well, as Rachel explained. 
I've had various situations where men in my company have asked each other questions about the PCs and ignored me completely and they know full well that I have much more knowledge about IT than they do. I've butted in with the answer it really annoys them. Now I take another tack-just let them talk and smugly gloat or laugh to myself. I don't offer until they ask. I get such pleasure out of seeing them struggle.

\section{CONCLUSIONS AND COMMENTS}

Certain themes have arisen from my qualitative enquiry. The gendered family in this UK-based study involves sexual division of labor and inequality in the share of domestic and household management tasks. Gender is shaping the use and domestication of ICTs. There are unequal time demands and competition for the time of women in the home with ensuing feelings of guilt aroused by role overload. There are conflicting uses of ICTs in the home and competition for these resources. Work and study impact in the home with the public creeping into the private sphere. Domestication of ICTs also reflects changes in household spaces occupied by ICTs and their use. ICT use in the home doesn't match the hype, which is that they will help with the education of kids and others, they will make life easier, and they will encourage inclusion in the digital society. Manufacturing and commercial visions and versions of the future, in terms of ICT use in the home, are contested. It is, therefore, crucial to consider how ICTs are appropriated and consumed in households, including an understanding of how the family and technologies are gendered. Analysis without this leaves gaping holes in understanding the future and yet again fails to appreciate the reality of women's gendered domestic lives. In these terms, Ward (2003, p. 18) emphasizes that the household is a space where technology is adopted, consumed, argued about, and - to varying degrees of success - integrated into domestic culture. Indeed the home is a contested domain - an arena where differing interests struggle to define their own spaces (Morley 2000, Silverstone and Hirsch 1992). Hynes (2002) stresses that the household has such a central role in our lives that there is a great need to document, analyze, and understand changes that are occurring in the ways in which people consume technologies in the domestic setting through their everyday lives. Not to do so is to give in to the corporate version and vision of the future.

My qualitative enquiry of gendered technologies in gendered households in the UK presented in this paper is clearly not exhaustive of the field. Issues of class, age, and ethnicity, for example, have not been deeply analyzed in this study. Yet in relation to taking critical research forward (Howcroft and Trauth 2004), this paper addressed this task set by discussing the political economy of the gendered household and the dynamic relationship and struggle between home and work arenas. It analyses how ICTs are embedded into everyday life and the gender shaping of ICTs, considers how empirical evidence suggests that, in the UK, ICTs in the home are a leisure and communication tool primarily and analyzes this in the light of government and commercial visions. It provides a rich analysis of ICT use in the gendered family and the contested political, social, and gender politics of the household. It challenges the status quo views of the domestication of ICTs in the UK and concludes that further work is clearly needed in this neglected area of research. 


\section{References}

Adam, A., Howcroft, D., and Richardson, H. "A Decade of Neglect: Reflecting on Gender and IS," New Technology Work and Employment (19:3), 2004, pp. 333-352.

Anderson, B., Gale, C., Gower, A. P., France, E. F., Jones, M. L. R., Lacohee, H. V., McWilliam, A., Tracey, K., and Trimby, M. "Digital Living-People Centered Innovation and Strategy," BT Technology Journal (20:2), April 2002, pp. 11-29.

Anderson, B., Gale, C., Gower, A. P., France, E. F., Jones, M. L. R., Lacohee, H. V., McWilliam, A., Tracey, K., and Trimby, M. "Family Life in the Digital Home-Domestic Technology at the End of the $20^{\text {th }}$ Century," BT Technology Journal (17:1), 1999, pp 85-97.

Baille, L., Benyon, D., Macaulay, C., and Pederson, M. G. "Investigating Design Issues in Household Environments," Cognition, Technology \& Work (5:1), 2003, pp. 33-43.

Boneva, B., Kraut, R., and Frohlich, D. "Using E-Mail for Personal Relationships: The Difference Gender Makes," American Behavioral Scientist (45:3), November 2001, pp. 530-549.

Brants, K., and Frissen, V. "Inclusion and Exclusion in the Information Society," Final Deliverable for the European Media and Technology in Everyday Life Network, 2000-2003, 2003 (available online through Research Results at www.emtel2.org).

Cronberg, T., and Sangregorio, I-L. "More of the Same: The Impact of IT on Domestic Life in Japan," Development Dialogue (2), 1981, pp. 68-78.

Faulkner, W. "The Technology Question in Feminism: A View from Feminist Technology Studies," Women's Studies International Forum (24:1), June 2000, pp. 79-95.

German, L. "Women's Liberation Today," International Socialism Journal (101), December 2003, pp. 3-43.

Green, E. "Technology, Leisure and Everyday Practices," in A. Green and A. Adam (eds.), Virtual Gender: Technology, Consumption and Identity Matters, London: Routledge, 2001, pp. 173-189.

Green, E., and Adam, A. "On-Line Leisure: Gender and ICTs in the Home," Information, Communication and Society (1:3), 1998, pp. 291-312.

Grint, K., and Gill, R. The Gender-Technology Relation: Contemporary Theory and Research, London: Taylor and Francis, 1995.

Habib, L., and Cornford, T. "Computers in the Home: Domestication and Gender," Information Technology \& People (15:2), 2002, pp. 159-174.

Haddon, L. "Explaining ICT Consumption: The Case of the Home Computer," in R. Silverstone and E. Hirsch (eds.), Consuming Technologies: Media and Information in Domestic Spaces, London: Routledge, 1992, pp. 82-96.

Harman, C. "From Common Sense to Good Sense," Socialist Review (292), January 2005, p. 17. Howcroft, D., and Trauth, E. "The Choice of Critical Information Systems Research," in B. Kaplan, D. P. Truex, D. Wastell, A. T. Wood-Harper, and J. I. DeGross (eds.), Information Systems Research: Relevant Theory and Informed Practice, Boston: Kluwer Academic Publishers, 2004, pp. 195-211.

Huws, U. The Making of a Cybertariat: Virtual Work in a Real World, London: The Merlin Press, 2003.

Hynes, D. "Digital Multimedia Consumption/Use in the Household Setting," paper presented at International Association for Media and Communications Research, Barcelona, Spain, July 21-26, 2002.

Kan, M. Y. "Gender Asymmetry in the Division of Domestic Labor," unpublished manuscript, Department of Sociology, University of Oxford, 2001 (available online at http://www.iser.essex.ac.uk/bhps/2001/docs/pdf/papers/kan.pdf).

Kay, T. "Women's Work and Women's Worth: The Leisure Implications of Women's Changing Employment Patterns," Leisure Studies (15), 1996, pp. 49-64. 
Kvasny, L. "The Existential Problem of Evil and IT in the Hotel Civilization," keynote speech presented to the Second International CRIS Workshop: Critical Reflections on Critical Research on Information Systems, July 14, 2004 (available online at www.isi.salford.ac.uk/ cris).

Kvasny, L., and Keil, M. "The Challenges of Redressing the Digital Divide: A Tale of Two US Cities," Information Systems Journal (16), 2006, pp. 23-53.

Mandelson, P. "Foreword" to Competitive Advantage in the Digital Economy, Department of Trade and Industry, London, 2001 (available online at http:/www.dti.gov.uk/comp/ competitive/pdfs/ec pdfl.pdf).

Maynard, E. M., and Pearsall, S. J. "What About Male Mature Students? A Comparison of the Experiences of Men and Women Students," Journal of Access Studies (9:2), 1994, pp. 229-240.

MINTEL. Family leisure Trends-UK, MINTEL International Group, Ltd., March 2000.

Moore, K. Versions of the Future in Relation to Mobile Communication Technologies, unpublished Ph.D. thesis, University of Surrey, United Kingdom, September 2003.

Morley, D. Home Territories Media Mobility and Identity, London: Routledge, 2000.

Patel, D., and Pearson, I. D. "Hype and Reality in the Future Home," BT Technology Journal (20:2), 2002, pp. 106-115.

Peters, P., and Raaijmakers, S. "Time Crunch and the Perception of Control Over Time from a Gendered Perspective: The Dutch Case," Society and Leisure (21:2), Autumn 1999, pp. 417-433

Phillips, P., Friday, A., and Cheverst, K. "Understanding Smart Environments: A Brief Classification," paper presented at the First Equator IRC Workshop on Ubiquitous Computing in Domestic Environments, University of Nottingham September 13-14, 2001 (available online at http://www.equator.ac.uk).

Richardson, H., and French, S. "Exercising Choices: The Gender Divide and Government Policy Making in the "Global Knowledge Economy," in The Transformation of Organizaitons in the Information Age: Social and Ethical Implicatoins (6 ${ }^{\text {th }}$ International ETHICOMP Conference), J. A. A. A. Lopes, D. I. Alvarez, S. Rogerson and T. Ward Bynum (eds.), Lisbon, November 2002.

Rout, P. A. "Digital Homes-For Richer For Poorer, Who Are They For?," BT Technology Journal (20:2), April 2002, pp. 96-105.

Silva, E. B. "The Politics of Consumption at Home: Practices and Dispositions in the Uses of Technologies," Pavis Papers in Social and Cultural Research, The Open University, Milton Keynes, UK, 2000.

Silverstone, R. "Media and Technology in the Everyday Life of European Societies," Final Deliverable to the European Media and Technology in Everyday Life Network, 2000-2003, 2003 (available online at Research Results on www.emtel2.org).

Silverstone, R., and Hirsch, E. Consuming Technologies: Media and Information in Domestic Spaces, London: Routledge, 1992.

Steward, J., and Williams, R. "The Wrong Trousers? Beyond the Design Fallacy: Social Learning and the User," in Handbook of Critical Information Systems Research Theory and Application, D. Howcroft and E. Trauth (eds.), Cheltenham, MA: Edward Elgar, 2005.

Tonkiss, F. "Using Focus Groups," in C. Seale (ed.), Researching Society and Culture, London: Sage Publications, 2004.

Venkatesh, A. "Computers and Other Interactive Technologies for the Home," Communications of the $A C M$ (39:12), 1996, pp. 47-54.

Wajcman, J. Feminism Confronts Technology, Cambridge, UK: Polity Press, 1991. 
Wajcman, J. "Reflections on Gender and Technology Studies: In What State is the Art?," Social Studies of Science (30:3), 2000, pp. 447-464.

Ward, K. "An Ethnographic Study of Internet Consumption in Ireland: Between Domesticity and Public Participation," Key Deliverable to the European Media and Technology in Everyday Life Network, 2000-2003, 2003 (available online at Research Results on www.emtel2.org).

Wharton, A. S. The Sociology of Gender, Oxford, UK: Blackwell. 2005.

Wilson, M., and Greenhill, A. "A Critical Deconstruction of Promises Made for Women on Behalf of Teleworking," Critical Reflections on Critical Research in Information Systems ( $2^{\text {nd }}$ International CRIS Workshop), A. Adam, A. Basden, H. Richardson, and B. Robinson (eds.), University of Salford, UK, July 14, 2004.

\section{About the Author}

Helen Richardson is a senior lecturer in Information Systems and joined the University of Salford in 1998 after a varied career including working in the field of Social Care and running a Research and Training Unit promoting Positive Action for Women at Work. She is engaged in critical research in IS including issues of gender in the ICT labor market. Helen can be reached at H.Richardson@salford.ac.uk 